\title{
Academic Qualification and Teachers' Job Satisfaction in Secondary Schools in Nakuru County-Kenya
}

\author{
-Margaret Maina: Department of Curriculum and Educational Management, Laikipia University, Kenya. \\ J. Kanjogu Kiumi: Department of Curriculum and Educational Management, Laikipia University, Kenya. \\ Peter Githae: Department of Curriculum and Educational Management, Laikipia University, Kenya.
}

\begin{abstract}
Teacher job satisfaction is one of the critical determinants of the rate of progress in students learning outcomes. The teaching profession in Kenya has in the recent past experienced industrial disharmony by way of teachers' strikes, which could be a pointer to dissatisfaction among teachers. Teacher dissatisfaction is typically rooted in failure by entities responsible for teacher management to meet teachers' needs. Research-based evidence demonstrates that employees have different needs and that these needs are influenced by factors such as employee's level of training or education for that matter. Drawing on these observations, the study sought to determine whether an academic qualification has any bearing on teachers' job satisfaction in secondary schools in Nakuru County, Kenya. Data was collected using a self-delivered questionnaire from 341 teachers who were randomly selected from 3,092 teachers in the study locale. The instrument's validity and reliability as estimated through split-half and Cronbach's alpha stood at $r=.945$ and $r=.905$ respectively. Collected data was analyzed using ANOVA statistic at .05 alpha level. A major finding of the study was that teacher satisfaction decreased with an increase in the level of academic qualification. Qualification-differentiated satisfaction was also statistically significant ( $p<.05)$. The study offers useful insights to the Teachers Service Commission (TSC) and school managers on how to enhance teachers' job satisfaction by way of addressing the needs of teachers in different levels of academic qualification.
\end{abstract}

Key words: Teachers, Job satisfaction, Academic qualification, Nakuru County, Kenya.

\section{Introduction}

Job satisfaction is an important and crucial factor in the workplace. Teachers' job satisfaction is very crucial to the long term growth of any educational system around the world. As Ololube (2006) points out, the significance of teacher satisfaction in an educational system is grounded on the fact that it has an appreciable influence on students' learning outcomes. For instance, a satisfied teacher is more likely to be engaged in a school setting, a factor that greatly enhances students' positive progress in the curriculum. The converse is likely to be the case among dissatisfied teachers. Such teachers, in most cases tend to have not only an irritable attitude, but also hostile behavioural tendencies towards their colleagues, learners and the wider society (Sankar \& Vasudha, 2015). Lim (2008) has further observed that job satisfaction has an appreciable influence on workers' psychological well-being and consequently organizational effectiveness. This implies that a satisfied worker is more likely to experience positive emotions and feelings of happiness, both of which are significant determinants of organizational commitment and output. The converse is true.

Teacher job satisfaction is not a group phenomenon since it is a function of an individual's needs fulfilment. In view of the fact that teachers differ in terms of temperament, interests and experience, Steers,

International Journal of Educational
Studies
Volume 4, Issue 3, pp. $75-80$
2021
DOI: 10.53935/2641-533x.v4i3.159
Corresponding Author: Margaret Maina
Funding: This study received no specific
financial support.
Article History:
Received: 25 August 2021
Revised: 27 September 2021
Accepted: 17 October 2021
Published: 9 December 2021
@ 2021 by the authors; licensee Academic
Publishing Group


Porter, and Bigley (1996) have pointed out that their needs and consequently levels of job satisfaction are different. The differential levels of job satisfaction are also linked to the fact that teachers are typically in different stages of career development (Okumbe, 1998). In view of teachers' heterogeinity, Evans (1998) has averred that the best approach in an attempt to study teacher satisfaction is to adopt the individuality dimension in which the focus is on individual characteristics such as academic qualification. Studies on the relationship between academic qualification and job satisfaction among teachers have however generated inconsistent findings. A study by Sonia (2010) found that level of education is a factor that determines the degree of job satisfaction since more educated persons have high expectations from their leaders which in most cases remain unmet. This implies that an increase in an employee's education may lower their job satisfaction. On the contrary, Dehaloo (2011) found out that teachers with bachelors and masters degrees were significantly more satisfied with their physical environments and overall school organization than teachers with lower qualifications. However, research by Otanga and Mange (2014) among primary school teachers in Kenya did not reveal any significant relationship between academic qualification and job satisfaction.

Although the foregoing studies have investigated job satisfaction in relation to academic qualification, they have not individualized satisfaction which is critical to the deep understanding of teachers' job satisfaction in the country. Furthermore, none of the studies has been done to investigate the influence of academic qualification on job satisfaction of secondary school teachers in Nakuru County, Kenya.

\section{Literature Review}

Previous studies on the link between teachers' job satisfaction and academic qualification have generated conflicting findings. For instance, a study in Nigeria by Akiri and Ugborugbo (2009) found that highly qualified teachers in Nigeria were the least satisfied. The study indicated that attainment beyond bachelors degree tends to lead to a mismatch between teachers' expectations and professional realities, thus lowering their level of job satisfaction. Similarly, a study by Manisha, Ashish, and Shikha (2019) in India found that the level of education had a strong negative correlation with job satisfaction $(r=-0.213)$, implying that satisfaction decreased with increase in education qualification. Other studies (Ekuwam, 2014; Eskildsen, 2004; Otube, 2004; Ram, 2012) came up with similar findings.

Tadesse and Muriithi (2017)study however established a linear and direct relationship between academic qualification and job satisfaction. This finding is consistent with the results of earlier studies by Wachira, Kalai, and Tanui (2015) and Lukuyani (2003). Other studies (for instance Devi and Nagini (2013); Gbadamosi and Joubert (2005)) did not establish any significant relationship between amount of worker's education and level of job satisfaction. Since the foregoing studies have presented conflicting findings on the influence of level of education on job satisfaction, the present study sought to shed more light in this area by investigating whether academic qualification has any influence on job satisfaction of secondary school teachers in Nakuru County, Kenya.

\section{Theoretical Framework}

The present study was informed by two theories: Job characteristics and Herzberg's (1957) two factor theories. Hackman and Oldham (1976) posit that there are five core job characteristics that determine the level of employee satisfaction. These are skill variety, task identity, task significance, autonomy and feedback. The theory further suggests that the five job characteristics lead to three critical psychological states which in turn influence individual and work outcomes such as job satisfaction, absenteeism, work motivation and level and quality of performance. In light of the postulations proffered by the theory, it can rightly be averred that, in order to realize maximum outputl from teachers, the working environment should offer opportunities for greater variety in teaching methodologies, freedom in task performance and enhanced responsibility. Herzberg's (1957) two factor theory holds that satisfaction and dissatisfaction in a work place are as a result of motivation and hygiene factors respectively. Motivator factors are intrinsic factors associated with higher order needs and include achievement, recognition and opportunities for advancement and growth. On the other hand, hygiene factors are extrinsic factors concerned with lower order needs and include supervision, 
salary, working conditions and job security. The theory posits that the two factors are distinct but not the opposite of each other. This implies that presence of intrinsic factors or motivators lead to job satisfaction, but their absence will not lead to job dissatisfaction. Therefore,teachers job satisfaction can be enhanced by concentrating on the motivators while taking care of the hygiene factors.

\subsection{Conceptual Framework}

The study presumed that job satisfaction (dependent variable) is dependent on academic qualification of the teacher (independent variable). The study further postulated that the link between the aforesaid variables was likely to be influenced (positively or negatively) by three extraneous variables: longevity in a school, teaching workload and the position held by the teacher in a school. The conceptualized relationship between the three categories of variables subsumed in the study is summarized schematically in Figure 1.

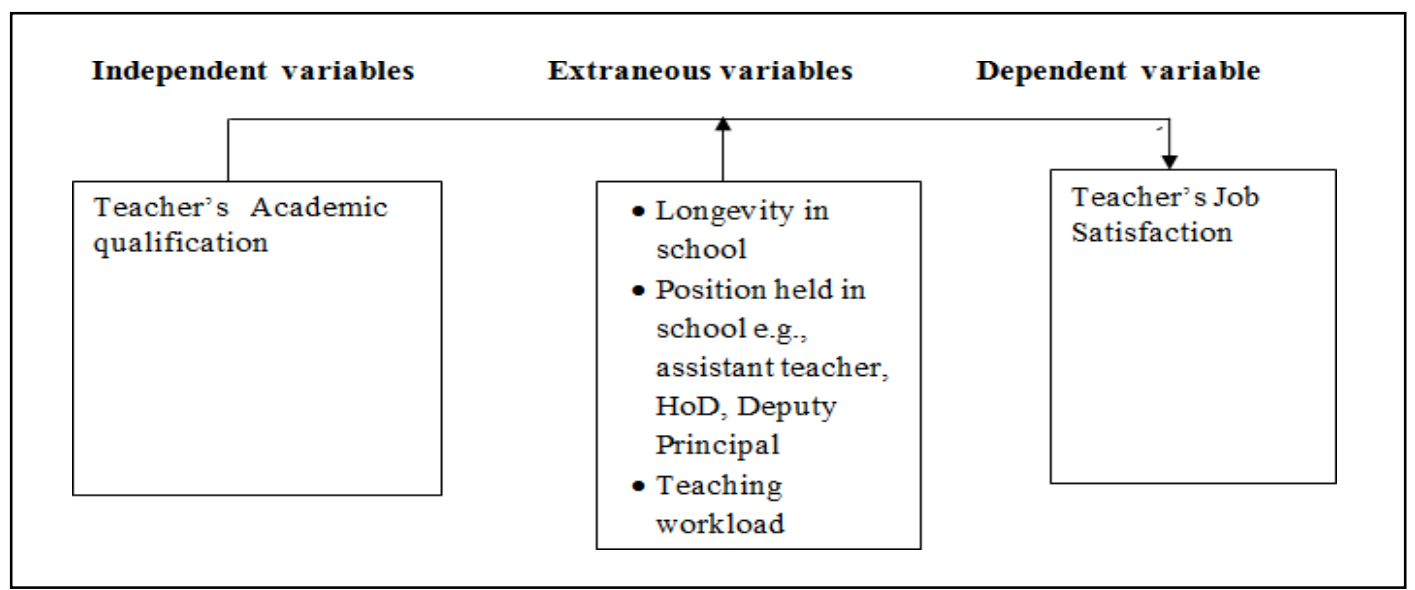

Figure-1. Hypothesized relationship among variables subsumed in the study.

Marczyk, Dematteo, and Festinger (2005) have averred that extraneous variables have the potential of generating rival/competing hypotheses that might explain the results of a study thereby compounding its internal validity. In this regard, the study controlled the three extraneous variables by randomly selecting teachers in the study area. This ensured that all teachers in the study area were given an equal chance of participating in the study irrespective of their background.

\section{Methodology}

The study used ex-post facto research design which according to Cohen and Manion (2012) is applied in studies where the independent and dependent variables have already interacted. Therefore, the researcher cannot manipulate the independent variable(s) with a view to determining its/their effect on the dependent variable(s). In this regard, the effect of the interaction between the two variables is determined retrospectively (Mugenda \& Mugenda, 2003). This design was chosen because the study purposed to establish the effect of academic qualification on job satisfaction retrospectively.

\section{Instrumentation}

The study used a questionnaire to collect the required data. The questionnaire was personally delivered to the 341 public secondary school teachers in the study area. The sample was selected by simple random and proportionate sampling techniques from a total population of 3,092 teachers. Selection of the sample was guided by Krejcie and Morgan (1970) table for determining sample sizes from given populations. The research instrument had 61 five-point likert scale items that measured various dimensions of teacher satisfaction. Respondents were requested to select the option that best suited them. The response options were labelled very dissatisfied, dissatisfied, slightly satisfied, satisfied and highly satisfied.

International Journal of Educational
Studies
Volume 4, Issue 3, pp. $75-80$
2021
DOI: 10.53935/2641-533x.v4i3.159
Corresponding Author: Margaret Maina
Funding: This study received no specific
financial support.
Article History:
Received: 25 August 2021
Revised: 27 September 2021
Accepted: 17 October 2021
Published: 9 December 2021
C 2021 by the authors; licensee Academic
Publishing Group




\subsection{Validity and Reliability of the Instrument}

The instrument was validated by carrying out a pilot study in the neighbouring Nyandarua County using 30 randomly selected teachers. The pilot group assessed the extent to which the 61 items in the instrument were adequately measuring job satisfaction. The results of the pilot study were used to make changes that were deemed necessary before execution of the main study.

External reliability of the instrument was estimated through split half technique. After administering the instrument to the pilot group, it was split into two halves of even and odd numbered items. Scores of the two sets of items were computed and in turn correlated. This computation generated a correlation coefficient of $\mathrm{R}=.905$. Internal reliability which determines the extent to which items in an instrument are measuring a single construct was tested using internal consistency technique in which Cronbach's coefficient alpha of .945 $(94.5 \%)$ was obtained. Therefore the instrument was considered to be internally consistent in measuring the construct of job satisfaction since according to Mugenda and Mugenda (2003) a coefficient of .70 (70\%) and above is deemed ideal in social sciences research.

\section{Results and Discussion}

Data analysis was done at two levels. First the job satisfaction mean scores for teachers with different academic qualifications were computed and in turn compared with a view to establishing whether they were significantly different. The computed mean scores are displayed in Table 1.

\begin{tabular}{|c|c|c|c|c|c|c|c|c|}
\hline & $\mathbf{N}$ & Mean & $\begin{array}{c}\text { Std. } \\
\text { Deviation }\end{array}$ & $\begin{array}{c}\text { Std. } \\
\text { Error }\end{array}$ & $\begin{array}{l}95 \% \\
\text { Interv }\end{array}$ & $\begin{array}{l}\text { Confidence } \\
\text { al for Mean }\end{array}$ & Minimum & Maximum \\
\hline & & & & & $\begin{array}{l}\text { Lower } \\
\text { Bound }\end{array}$ & Upper Bound & & \\
\hline Diploma & 40 & 4.3750 & .49029 & .07752 & 4.2182 & 4.5318 & 4.00 & 5.00 \\
\hline Bachelors & 254 & 3.6457 & .47925 & .03007 & 3.5864 & 3.7049 & 3.00 & 4.00 \\
\hline Masters & 26 & 1.8846 & .71144 & .13953 & 1.5973 & 2.1720 & 1.00 & 3.00 \\
\hline Total & 320 & 3.5938 & .75365 & .04213 & 3.5109 & 3.6766 & 1.00 & 5.00 \\
\hline
\end{tabular}

According to the results in Table 1, job satisfaction scores decreased with increase in academic qualification. This implies that an increase in level of education of a teacher has a negative effect on job satisfaction. The findings are in agreement with those of Ram (2012) whose study observed that there was a negative relationship between education and job satisfaction. Similarly, a study by Manisha et al. (2019) in India found that level of education had a strong negative correlation with job satisfaction. The mean scores were further subjected to one-way ANOVA in order to establish whether the observed differences were significant or not. This analysis was done to confirm the truth of the assumption held by the hypothesis which was stated as follows:

$\mathrm{Ho}_{1}$. Academic qualification has no statistically significant difference on teachers' job satisfaction levels in public secondary schools in Nakuru County, Kenya.

The outcome of this analysis is presented in Table 2.

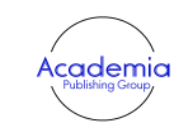

International Journal of Educational Studies

Volume 4, Issue 3, pp. 75-80 2021

DOI: $10.53935 / 2641-533 x . v 4 i 3.159$

Corresponding Author: Margaret Maina Funding: This study received no specific financial support.

Article History:

Received: 25 August 2021

Revised: 27 September 2021

Accepted: 17 October 2021

Published: 9 December 2021

(C) 2021 by the authors; licensee Academic Publishing Group
Table-2. ANOVA Summary on Teachers' Job Satisfaction by Academic Qualification.

\begin{tabular}{cccccc}
\multicolumn{7}{c}{ Table-2. ANOVA Summary on Teachers' Job Satisfaction by Academic Qualification. } \\
\hline & \multicolumn{7}{c}{ Source of variance } & F & Sig. \\
\hline Between Groups & 101.048 & 2 & 50.524 & 199.855 & .000 \\
Within Groups & 80.139 & 317 & .253 & \\
Total & 181.188 & 319 & & \\
\hline Source: Field & & & & & \\
\end{tabular}

An observation of the data shown in Table 2 indicates that the computed F-value $(\mathrm{F}=199.855 ; \mathrm{p}=.000)$ was statistically significant. Therefore the null hypothesis was rejected $(p<.05)$ and conclusion made that teachers' level of education significantly influenced their level of job satisfaction. In order to determine the 
groups of teachers whose job satisfaction scores were significantly different, Turkey's post hoc test was computed and the results summarized in Table 3.

\begin{tabular}{|c|c|c|c|c|c|c|}
\hline \multirow{2}{*}{$\begin{array}{l}\text { (I) Academic } \\
\text { Qualification }\end{array}$} & \multirow{2}{*}{$\begin{array}{l}\text { (J) Academic } \\
\text { Qualification }\end{array}$} & \multirow{2}{*}{$\begin{array}{c}\text { Mean } \\
\text { Difference (I- } \\
\text { J) }\end{array}$} & \multirow[t]{2}{*}{ Std. Error } & \multirow[t]{2}{*}{ Sig. } & \multicolumn{2}{|c|}{$95 \%$ Confidence Interval } \\
\hline & & & & & $\begin{array}{l}\text { Lower } \\
\text { Bound }\end{array}$ & $\begin{array}{l}\text { Upper } \\
\text { Bound }\end{array}$ \\
\hline \multirow[t]{2}{*}{ Diploma } & Bachelors & $.7293^{*}$ & .08553 & .000 & .5279 & .9307 \\
\hline & Masters & $2.4904^{*}$ & .12666 & .000 & 2.1921 & 2.7886 \\
\hline \multirow[t]{2}{*}{ Bachelors } & Diploma & $-.7293^{*}$ & .08553 & .000 & -.9307 & -.5279 \\
\hline & Masters & $1.7611^{*}$ & .10353 & .000 & 1.5173 & 2.0048 \\
\hline \multirow[t]{3}{*}{ Masters } & Diploma & $-2.4904^{*}$ & .12666 & .000 & -2.7886 & -2.1921 \\
\hline & Bachelors & $-1.7611^{*}$ & .10353 & .000 & -2.0048 & -1.5173 \\
\hline & & Based on ob & served means & & & \\
\hline
\end{tabular}

The data in Table 3 shows that there were significant differences $(p<.05)$ among the 3 categories of teachers. This implies that job satisfaction of secondary school teachers in Nakuru County differed according to their level of education. These findings tend to differ with those of Devi and Nagini (2013) whose research reported that there was no significant difference between academic qualification and job satisfaction. Similarly, Mengistu (2012) study in Ethiopia showed that there were no statistically significant differences in job satisfaction between groups with different academic qualifications.

\section{Recommendation and Conclusion}

The findings generated by the study have important implications and lessons in regard to enhancing teachers' job satisfaction. A major observation is that higher academic achievement decreases the level of job satisfaction among secondary school teachers. Consequently, teacher employer in Kenya, specifically the Teachers Service Commission (TSC) needs to recognize teachers who advance their education by promoting them to a higher job group. In addition, principals should recognize teachers who advance their education by appointing them to positions with more responsibilities in their respective schools.

\section{References}

Akiri, A. A., \& Ugborugbo, N. M. (2009). Analytic examination of teachers' career satisfaction in public secondary schools. Studies on Home and Community Science, 3(1), 51-56.Available at: https://doi.org/10.1080/09737189.2009.11885276.

Cohen, L., \& Manion, L. (2012). Research methods in education. London: Routledge Falmer.

Dehaloo, G. (2011). The motivation and job satisfaction of secondary school teachers in Kwazulu-Natal: An education management perspective. Unpublished Doctoral Thesis. University of South Africa.

Devi, V. R., \& Nagini, A. (2013). An investigation of factors influencing job satisfaction of employees in banking sector of India International Journal of Research in Organizational Behaviour and Human Resource Management, 1(3), 107-115.

Ekuwam, I. S. (2014). Determinants of job satisfaction among teachers in public primary schools in Turkana West Sub-county, Kenya Unpublished Masters Thesis. University of Nairobi.

Eskildsen, J. K. (2004). Work motivation and job satisfaction in the Nordic countries. Employee Relations, 26(112), 122-136.

Evans, L. (1998). Teacher morale, job satisfaction and motivation. London: Paul Chapman Publishing Ltd.

Gbadamosi, G., \& Joubert, P. (2005). Money ethic, moral conduct and work related attitudes: Field study from the public sector in Swaziland. The Journal of Management Development, 24(8), 754-763.

Hackman, J. R., \& Oldham, G. R. (1976). Motivation through the design of work: Test of a theory. Organizational Behavior and Human Performance, 16(2), 250-279.

International Journal of Educational Studies

Volume 4, Issue 3, pp. 75-80

2021

DOI: $10.53935 / 2641-533 x . v 4 i 3.159$

Corresponding Author: Margaret Maina Funding: This study received no specific financial support.

Received: 25 August 2021

Revised: 27 September 2021

Accepted: 17 October 2021

Published: 9 December 202I

(C) 2021 by the authors; licensee Academic Publishing Group
Herzberg's, F. (1957). One more time: How do you motivate employees? Harvard Business Review, 46, 53-62.

Krejcie, R. V., \& Morgan, D. W. (1970). Determining sample size for research activities. Educational and Psychological Measurement, 30(3), 607-610.

Lim, S. (2008). Job satisfaction of information technology workers in academic libraries. Library \& Information Science Research, 30(2), 115-121.

Lukuyani, M. (2003). A study of the factors contributing to job satisfaction and dissatisfaction among secondary school teachers in Turkana district. Unpublished MED Thesis. University of Nairobi.

Manisha, G., Ashish, K. D., \& Shikha, G. (2019). Impact of education qualification on job satisfaction. European Journal of Business and Social Sciences, 7(5), 309-318. 
Marczyk, G., Dematteo, D., \& Festinger, D. (2005). Essentials of research design and methodology. New Jersey: John Wiley and Sons Inc.

Mengistu, G. K. (2012). Job satisfaction of secondary school teachers in Ethiopia. Unpublished Doctoral Thesis. University of South Africa.

Mugenda, M. O., \& Mugenda, A. G. (2003). Research methods in qualitative and quantitative approaches. Nairobi: Acts Press.

Okumbe, J. A. (1998). Education management: Theory and practice: Nairobi University Press.

Ololube, N. (2006). Teachers' job satisfaction and motivation for school effectiveness: An assessment: University of Helsinki.

Otanga, H., \& Mange, D. (2014). Contribution of personal characteristics and school context factors to job satisfaction among primary school teachers in Coast Province, Kenya. International Journal of Education and Research, 2(7), 469-480.

Otube, N. W. (2004). Job motivation of teachers educating learners with special needs in four provinces in Kenya. Unpublished Doctoral Dissertation. University of Hamburg.

Ram, P. (2012). Post privatisation job satisfaction among employees. International Journal of Academic Research in Busia and Social Sciences, 2(1), 1-10.

Sankar, V. S., \& Vasudha, P. (2015). Job satisfaction of primary school teachers. Indian Psychological Foundation, 3(2), 45-52.

Sonia, J. (2010). Organizational commitment and job satisfaction: A study of employees in the Information Technology Industry in Bangalore, India. Unpublished Dissertation. Christ University: Bangalore.

Steers, R. M., Porter, L. W., \& Bigley, G. A. (1996). Motivation and leadership at work. New York: McGraw-Hill.

Tadesse, B., \& Muriithi, G. (2017). The influence of employee demographic factors on job satisfaction: A case study of Segen Construction Company, Eritrea. African Journal of Business Management, 11(21), 608-618.

Wachira, T., Kalai, J. M., \& Tanui, K. E. (2015). Relationship between demographic characteristics and leadership styles on teachers' job satisfaction in primary schools, Kenya: A case of Nakuru County. International Journal of Science and Research, 5(10), 25-29.

International Journal of Educational
Studies
Volume 4, Issue 3, pp. $75-80$
2021
DOI: $10.53935 / 2641-533 x . v 4 i 3.159$
Corresponding Author: Margaret Maina
Funding: This study received no specific
financial support.
Article History:
Received: 25 August 2021
Revised: 27 September 2021
Accepted: 17 October 2021
Published: 9 December 2021
() 2021 by the authors; licensee Academic
Publishing Group

Publishing Group 